\title{
Pseudoalteromonas arctica sp. nov., an aerobic, psychrotolerant, marine bacterium isolated from Spitzbergen
}

Correspondence

Garabed Antranikian

Antranikian@tuhh.de

\author{
Rami Al Khudary, Nele Isabelle Stößer, Farah Qoura \\ and Garabed Antranikian
}

\author{
Institute of Technical Microbiology, Hamburg University of Technology, Kasernenstr. 12, 21073 \\ Hamburg, Germany
}

Marine Pseudomonas-like bacteria comprise several related genera, including Alteromonas, Marinomonas, Pseudoalteromonas, Moritella, Marinobacter, Psychrobacter, Colwellia, Shewanella, Halomonas and several others. Classification of these aerobic heterotrophic micro-organisms from the marine environment remains difficult and time-consuming due to their phenotypic diversity and the absence of robust chemotaxonomic markers. Fortunately, phylogenetic information based on 16S rRNA gene sequences is useful in classifying and identifying micro-organisms belonging to previously poorly defined taxa (Ivanova et al., 2000).

The genus Pseudoalteromonas, originally called Alteromonas, includes non-pigmented, Gram-negative, heterotrophic, aerobic, polar-flagellated species of marine bacteria that have DNA $\mathrm{G}+\mathrm{C}$ contents ranging from 38 to $50 \mathrm{~mol} \%$. These characteristics differentiate this bacterial group from the previously described genus Pseudomonas. Since Baumann et al. (1972) proposed the genus Alteromonas in 1972, several species have been assigned to this genus. A recent revision of the genera based on phylogenetic analysis (Gauthier et al., 1995) divided the

Abbreviations: FAME, fatty acid methyl ester; AZCL, azurine-crosslinked. The GenBank/EMBL/DDBJ accession number for the 16S rRNA gene sequence of strain A $37-1-2^{\top}$ is DQ787199. genus Alteromonas into two genera, Pseudoalteromonas and Alteromonas.

Pseudoalteromonas is one of the largest genera within the class Gammaproteobacteria and currently comprises more than 30 species (Ivanova et al., 2004). These bacteria play an important role in marine environments owing to their abundance and high metabolic activities. Pseudoalteromonads are highly capable of surviving in nutrient-poor marine environment by adjustment of their biochemical pathways and production of a wide variety of metabolites, including biologically active compounds and enzymes (Ivanova et al., 2003).

In this study, a novel aerobic bacterium was isolated from ice and seawater samples obtained from the area of Spitzbergen in the Arctic. This novel isolate was found to belong to the genus Pseudoalteromonas. Taxonomic and physiological analysis of this isolate demonstrated that it represents a novel species of the genus Pseudoalteromonas.

Arctic sea ice and seawater samples were collected from Spitzbergen, Norway, and transported to the laboratory at an ambient temperature of $10{ }^{\circ} \mathrm{C}$. A $1 \mathrm{ml}$ aliquot of each of the 50 liquid samples was incubated at $4{ }^{\circ} \mathrm{C}$ in a complex marine aerobic liquid medium named EMP-2 (enrichment medium for psychrophiles 2). This medium consisted of a basal medium supplemented with a mixture of different 
carbon sources. The basal medium contained $\left(\mathrm{g} \mathrm{l}^{-1}\right)$ : $28.13 \mathrm{~g} \mathrm{NaCl}, 0.77 \mathrm{~g} \mathrm{KCl}, 0.02 \mathrm{~g} \mathrm{CaCl}_{2} .2 \mathrm{H}_{2} \mathrm{O}, 0.5 \mathrm{~g}$ $\mathrm{MgSO}_{4} \cdot 7 \mathrm{H}_{2} \mathrm{O}, 1.0 \mathrm{~g} \mathrm{NH}_{4} \mathrm{Cl}, 0.02 \mathrm{~g}$ iron ammonium citrate, $0.5 \mathrm{~g}$ yeast extract, $1 \mathrm{ml} 10$-fold concentration trace element solution (from DSMZ medium 141), $1 \mathrm{ml}$ 10 -fold concentration vitamin solution (from DSMZ medium 141), $2.3 \mathrm{~g} \mathrm{KH}_{2} \mathrm{PO}_{4}$ and $2.9 \mathrm{~g} \mathrm{Na}_{2} \mathrm{HPO}_{4} \cdot 2 \mathrm{H}_{2} \mathrm{O}$. Carbon sources were added at the following concentrations $\left(\mathrm{g} \mathrm{l}^{-1}\right)$ : $0.5 \mathrm{~g}$ sodium acetate, $0.5 \mathrm{~g}$ disodium succinate, $0.5 \mathrm{~g}$ sodium pyruvate, $0.5 \mathrm{~g}$ DL-malate, $0.5 \mathrm{~g}$ D-mannitol and $2 \mathrm{~g}$ glucose. The final $\mathrm{pH}$ of the medium was 7.0. Incubation was carried out at $4{ }^{\circ} \mathrm{C}$ for about $4-7$ days before growth and colonies were observed on agar plates. Colonies were selected on the basis of morphological differences. For the isolation of a pure culture, serial dilution and plating techniques were applied. The pure isolates were routinely cultivated on EMP-2 agar plates containing $2 \%(\mathrm{w} / \mathrm{v})$ agar at $15{ }^{\circ} \mathrm{C}$ for 4 days.

The Gram staining test was performed using the Hucker method (Gerhardt et al., 1994). For the sporulation test, cells were grown for up to 6 days in basal medium. The presence of spores and the morphology of the cells were determined by phase-contrast microscopy (Zeiss/ Axioskop).

The maximal growth temperature was tested in the complex medium between 4 and $35{ }^{\circ} \mathrm{C}$ at $\mathrm{pH}$ 7.0. The $\mathrm{pH}$ range for growth was determined by testing between $\mathrm{pH} 2$ and 10 at $15{ }^{\circ} \mathrm{C}$. The salt requirement was determined at different $\mathrm{NaCl}$ concentrations ranging from 0 to $10 \%(\mathrm{w} / \mathrm{v})$, with no change in the other salt component concentrations at $\mathrm{pH} 7.0$ and $15{ }^{\circ} \mathrm{C}$. Growth was measured by determining the $\mathrm{OD}_{600}$.

Substrate utilization was tested on API 20NE strips (bioMérieux), API 20E strips (bioMérieux) and Biolog GN2 microplates. API 20NE and API 20E strips were also used for testing the ability of the novel strain to produce indole (from tryptophan), acetoin and $\mathrm{H}_{2} \mathrm{~S}$ (from sodium thiosulfate) and to reduce nitrate to nitrite and nitrite to nitrogen. Carbohydrate metabolism was also tested using API 50CH strips (bioMérieux).

The strips and microplates were inoculated with a cell suspension that was grown on complex medium [cells were resuspended in $0.85 \%(\mathrm{w} / \mathrm{v}) \mathrm{NaCl}$ to a final $\mathrm{OD}_{600}$ of 1.0$]$ and incubated at $15{ }^{\circ} \mathrm{C}$ overnight.

Enzyme formation by the isolated aerobic strain was tested on diffusion agar plates containing the basal medium and $0.1 \%(\mathrm{w} / \mathrm{v})$ of one of the following substrates: red pullulan (pullulanase), azo-casein (protease), azurine-crosslinked (AZCL)-pullulan (pullulanase), AZCL-HE-cellulose (cellulase), AZCL-arabinan (arabinase), AZCL-arabinoxylan (arabinoxylanase), AZCL-curdlan (curdlanase), AZCLamylose (amylase), AZCL-dextran (dextranase), AZCLgalactan (galactanase), AZCL-galactomannan (galactomannanase), AZCL- $\beta$-glucan ( $\beta$-glucanase), AZCL-xylan (xylanase) and AZCL-xyloglucan (xyloglucanase).
Substrate degradation was detected by a clearing zone/ colour diffusion halo around the colonies after growth on agar plates at $10{ }^{\circ} \mathrm{C}$ for $2-4$ days. AZCL polymers were purchased from Megazyme.

Cells of the isolated strain were harvested by centrifugation after growth in 21 complex medium at $15^{\circ} \mathrm{C}$ and $\mathrm{pH} 7.0$ and were used for fatty acid analysis. Fatty acid methyl ester (FAME) analysis was performed according to the method of Kämpfer \& Kroppenstedt (1996) using minor modifications of the methods of Miller (1982) and Kuykendall et al. (1988). The FAME mixtures were separated using the Sherlock Microbial Identification system (MIS; MIDI), which consisted of an Agilent model 6890N GC fitted with a $5 \%$ phenyl-methyl polysiloxane capillary column $(0.2 \mathrm{~mm} \times 25 \mathrm{~m})$, a flame-ionization detector, an Agilent model 7683A automatic sampler and a Hewlett-Packard computer with the MIDI database. Peaks were automatically integrated and fatty acid names and percentages were calculated using the MIS Standard Software (Microbial ID).

GC parameters were as follows: carrier gas, ultra-highpurity hydrogen; column head pressure, $60 \mathrm{kPa}$; injection volume, $2 \mu \mathrm{l}$; column split ratio, 100:1; septum purge, $5 \mathrm{ml} \mathrm{min}{ }^{-1}$; column temperature, $170-270{ }^{\circ} \mathrm{C}$ at $5{ }^{\circ} \mathrm{C} \min ^{-1}$; injection port temperature, $240{ }^{\circ} \mathrm{C}$; and detector temperature, $300{ }^{\circ} \mathrm{C}$.

For $16 \mathrm{~S}$ rRNA gene amplification and sequencing, cells were harvested from a $500 \mu \mathrm{l}$ culture sample by centrifugation and resuspended in $100 \mu \mathrm{l}$ water. A sample of $1 \mu \mathrm{l}$ was used as a template for amplification of the 16S rRNA gene. PCR-mediated amplification of the 16S rRNA gene was carried out according to Rainey \& Stackebrandt (1993). PCR products were purified using the QIAquick PCR purification kit (Qiagen). Purified PCR products were sequenced directly using the Tag Dye Deoxy Terminator Cycle sequencing kit (Applied Biosystems). PCR products were electrophoresed using an Applied Biosystems model 373 S DNA sequencer. Both strands of amplification products were sequenced using primers $8 \mathrm{~F}, 518 \mathrm{~F}$ and 1504R (Buchholz-Cleven et al., 1997). The complete 16S rRNA gene sequence of the isolated strains was determined by the assembly of all sequence products using Vector NTI Advance 9.1 (Invitrogen) software.

BLAST analysis of the 16S rRNA gene sequence was carried out using the NCBI online database to determine the phylogenetic grouping to which the isolated strains were most closely related. Reference sequences utilized in phylogenetic analysis were retrieved from the NCBI database and aligned with the newly determined sequences of the isolated strains by using CLUSTAL W (1.83) software. Phylogenetic and molecular evolutionary analysis was performed by the neighbour-joining method by using the software PHYLIP version 3.65 (Felsenstein, 1995). The DNADIST program with the Kimura-2 factor was used to compute the pairwise evolutionary distances for the above aligned sequences (Kimura, 1980). Topology of the phylogenetic trees was evaluated by performing a bootstrap 
(algorithm version 3.6b) with 1000 bootstrapped trials. Phylogenetic trees were drawn using TREEVIEW 32 software (Fig. 1).

The 16S rRNA gene sequence data of the isolated aerobic strain were compared to the available sequences of micro- organisms belonging to the genus Pseudoalteromonas and related micro-organisms.

Cells of the isolated strains were harvested by centrifugation after growth at $15{ }^{\circ} \mathrm{C}$ on 21 complex medium and used for determination of the genomic DNA $\mathrm{G}+\mathrm{C}$

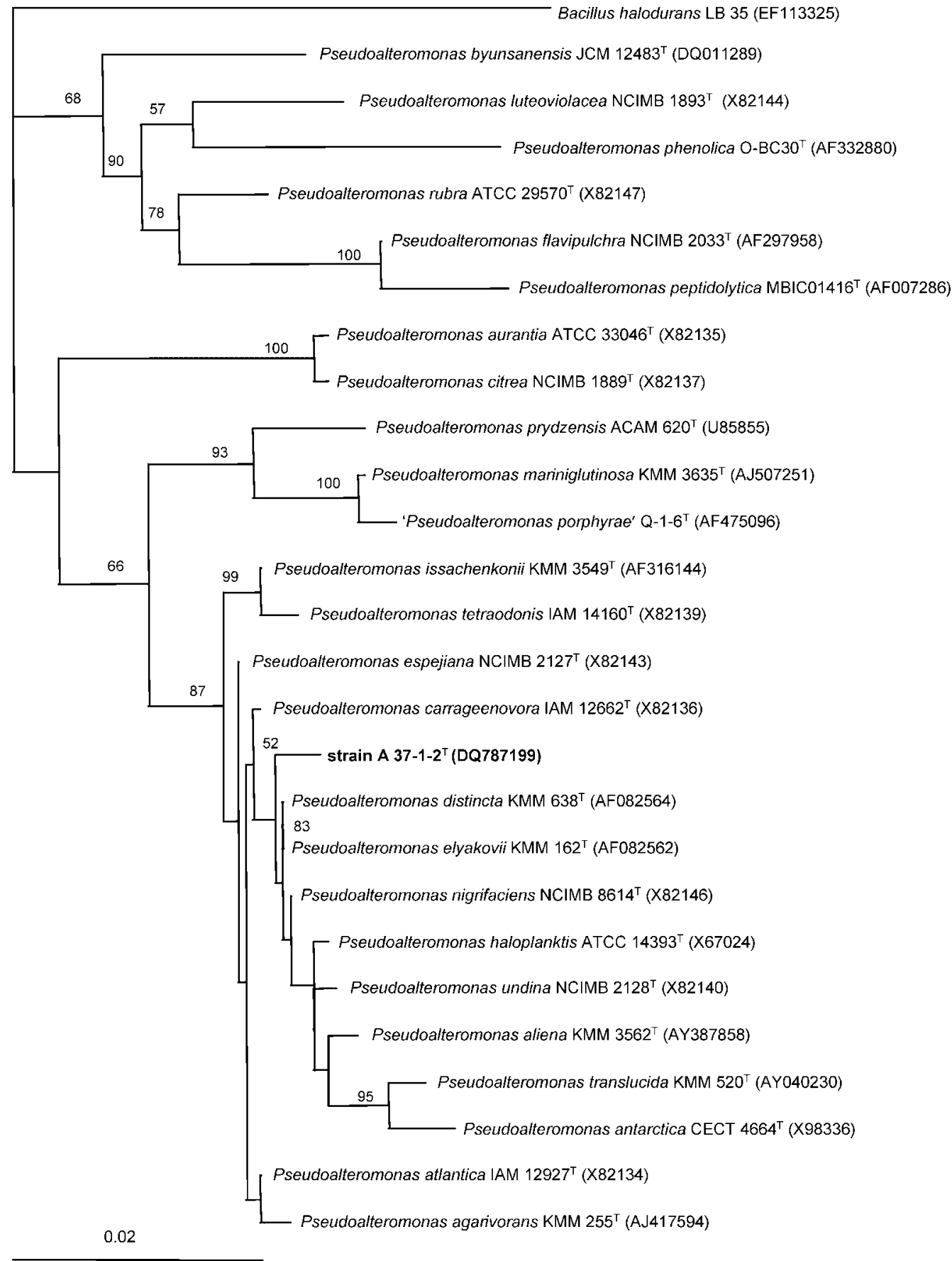

Fig. 1. Phylogenetic dendrogram based on $16 \mathrm{~S}$ rRNA gene sequence (1.499 kb) comparisons indicating the position of strain A 37-1-2 ${ }^{\top}$ within the genus Pseudoalteromonas. Analysis was performed by the neighbour-joining method using software from PHYLIP version 3.65 (see text for further details). Bacillus halodurans LB 35 was used as the outgroup. Bar, 2 nt substitutions per 100 nt. Significant bootstrap values (\%) are given at the nodes. 
content. Cells were disrupted with a French press and purified by chromatography on a hydroxyapatite column (Cashion et al., 1977). The DNA G+C content was determined by HPLC (Shimadzu) (Mesbah \& Whitman, 1989). The analytical column used was a Vydac 201 SP 54, C18 $5 \mu \mathrm{m}(250 \times 4.6 \mathrm{~mm})$ equipped with a guard column 201 GD 54H (Vydac).

DNA-DNA hybridization of the novel isolate with the reference strains Pseudoalteromonas elyakovii LMG $14908^{\mathrm{T}}$, Pseudoalteromonas distincta KMM $638^{\mathrm{T}}$ and Pseudoalteromonas nigrifaciens DSM $8810^{\mathrm{T}}$ was carried out using $3 \mathrm{~g}$ cell mass of each strain. To isolate the DNA, cells were French-pressed (Thermo Spectronic) and DNA was purified by chromatography on a hydroxyapatite column as described by Cashion et al. (1977). DNA-DNA hybridization was carried out as described by De Ley et al. (1970), with the modification described by Huß et al. (1983). In the case of $P$. elyakovii, a model 2600 spectrophotometer equipped with a model $2527-\mathrm{R}$ thermoprogrammer and plotter (Gilford Instrument Laboratories) was used. A Cary 100 Bio UV/VIS-spectrometer equipped with a Peltier thermostatted $6 \times 6$ multicell changer and a temperature controller with an in situ temperature probe (Varian) was used in the case of $P$. distincta and $P$. nigrifaciens. Renaturation rates were computed with the TRANSFER.BAS program of Jahnke (1992).

Enrichment cultures (pH 7) inoculated with seawater samples from Spitzbergen showed bacterial growth after 1 week of aerobic incubation at $4{ }^{\circ} \mathrm{C}$. Microscopy revealed the presence of short-rod-shaped cells. After a number of serial dilutions, one strain (A 37-1-2 ${ }^{\mathrm{T}}$ ) was investigated further.

As observed for members of the genus Pseudoalteromonas, cells of the newly isolated strain were Gram-negative, motile, polar-flagellated, short rods $(0.15-0.2 \mu \mathrm{m}$ wide and 0.4-0.75 $\mu \mathrm{m}$ long) (Bozal et al., 1997; Ivanova et al., 2000, 2004; Romanenko et al., 2003; Sawabe et al., 2000). They occurred as single cells or in pairs. Spores were not detected. A comparison of the morphological characteristics of the isolated strain and related strains is shown in Table 1.

No growth was observed under anaerobic conditions with glucose. Growth occurred only under aerobic conditions between 4 and $25{ }^{\circ} \mathrm{C}$. The optimal growth temperature and $\mathrm{pH}$ of the novel strain $\left(10-15{ }^{\circ} \mathrm{C}\right.$ and $\left.\mathrm{pH} 7-8\right)$ were similar to those of Pseudoalteromonas antarctica $\left(10-15{ }^{\circ} \mathrm{C}\right.$ and pH 7-8). Only a few Pseudoalteromonas strains show growth at $4{ }^{\circ} \mathrm{C}$; these include Pseudoalteromonas espejiana, Pseudoalteromonas carrageenovora and Pseudoalteromonas haloplanktis. The newly isolated strain grew in the presence of a wide range of $\mathrm{NaCl}$ concentrations, from 0 to $9 \%$ $(\mathrm{w} / \mathrm{v})$ [optimum 2-3\% (w/v)], which is broader than the range for $P$. distincta $(0.5-8 \%)$ and Pseudoalteromonas aliena (0.5-6\%), (Bozal et al., 1997; Ivanova et al., 2004).
Strain A $37-1-2^{\mathrm{T}}$ was able to utilize a large number of substrates, including $\alpha$-cyclodextrin, dextrin, cellobiose, Dgalactose, $\alpha$-D-glucose, maltose, D-mannitol, melibiose, sucrose, pyruvic acid methyl ester, D-gluconic acid, Lalanine, L-alanylglycine, glycyl-L-glutamic acid, L-serine, aesculin, ferric citrate and capric acid. P. elyakovii, $P$. espejiana, Pseudoalteromonas citrea and the novel isolate shared the ability to utilize D-galactose, sucrose, maltose, melibiose, D-mannitol and pyruvate. Only P. haloplanktis, $P$. nigrifaciens and the novel isolate were able to utilize D-gluconate.

The isolated strain produced several enzymes: pullulanase, caseinase, $\beta$-glucanase, esterase, pectinase, $\beta$-glucosidase and $\beta$-galactosidase. $P$. aliena, $P$. antarctica and Pseudoalteromonas agarivorans are known to produce caseinase (Bozal et al., 1997; Ivanova et al., 2004; Romanenko et al., 2003). P. agarivorans produces an esterase and a $\beta$-galactosidase (Bozal et al., 1997).

The FAME composition of the novel strain after growth at the optimal temperature of $15{ }^{\circ} \mathrm{C}$ is shown in Table 2 . The FAME profiles display only those fatty acids comprising $\geqslant 0.05 \%$ of the total. Straight-chain saturated FAMEs comprised $20.3 \%$, terminally branched saturated FAMEs comprised $20.2 \%$ and monounsaturated FAMEs comprised $56.1 \%$. The monounsaturated FAME 16:1 $1 \omega 7 c$ $(40.2 \%)$ was the most abundant FAME found. Interestingly, the high content of monounsaturated fatty acids in the isolate is a characteristic of psychrophilic micro-organisms where the lipid bilayers of psychrophilic cells are composed mostly of cis-unsaturated double bond chains, which create a $30^{\circ}$ bend resulting in formation of cavities in the lipid layer, thus reducing packing density and maintaining fluidity in near- or subfreezing conditions (Deming, 2002; Feller \& Gerday, 2003). The FAME composition of the isolate and related strains belonging to the genus Pseudoalteromonas is listed in Table 2.

The $\mathrm{G}+\mathrm{C}$ content of the DNA from the novel isolate is $39.0 \mathrm{~mol} \%$. The $16 \mathrm{~S}$ rRNA gene sequence $(1.499 \mathrm{~kb})$ was analysed and compared to available 16S rRNA gene sequences of organisms belonging to the genus Pseudoalteromonas. The most closely related species, with 16S rRNA gene sequence similarities of $99 \%$, were $P$. elyakovii (1484 out of $1489 \mathrm{nt}$; $99.7 \%$ sequence similarity), P. citrea (1469/1474 nt; 99.7\%), P. haloplanktis (1484/ $1494 \mathrm{nt} ; 99.3 \%)$, P. distincta (1473/1481 nt; $99.5 \%), P$. agarivorans (1475/1484 nt; $99.4 \%$ ) and Pseudoalteromonas gracilis (1484/1494 nt; 99.3\%). Although the level of $16 \mathrm{~S}$ rRNA similarity with the closest relative (99\%) is high for two species, the observed value is still low for the mean level of similarity within the genus (Gauthier et al., 1995). Strain A $37-1-2^{\mathrm{T}}$ formed a cluster with $P$. elyakovii and $P$. distincta. Hybridization of DNA of strain A $37-1-2^{\mathrm{T}}$ with that of the most related strains, i.e. P. elyakovii, $P$. distincta and P. nigrifaciens, showed only $47.6,44.2$ and $22.6 \%$ DNA-DNA relatedness, respectively, despite the fact that the $16 \mathrm{~S}$ rRNA gene sequence similarity between all of them 
Table 1. Comparative characteristics of strain A $37-1-2^{\top}$ and related members of the genus Pseudoalteromonas

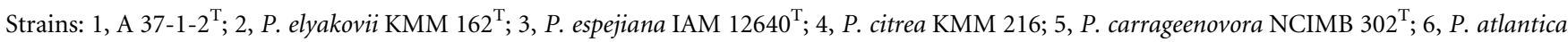
NCIMB $301^{\mathrm{T}} ; 7$, P. distincta KMM $638^{\mathrm{T}} ; 8$, P. haloplanktis IAM $12915^{\mathrm{T}}$ (Sawabe et al., 2000); 9, P. tetraodonis IAM 14160 ${ }^{\mathrm{T}}$; 10, P. antarctica CECT $4664^{\mathrm{T}}$; 11, P. nigrifaciens IAM $13010^{\mathrm{T}}$; 12, P. undina NCIMB $2128^{\mathrm{T}}$ (Ivanova et al., 2001, 2002). +, Positive; -, negative; ND, no data available.

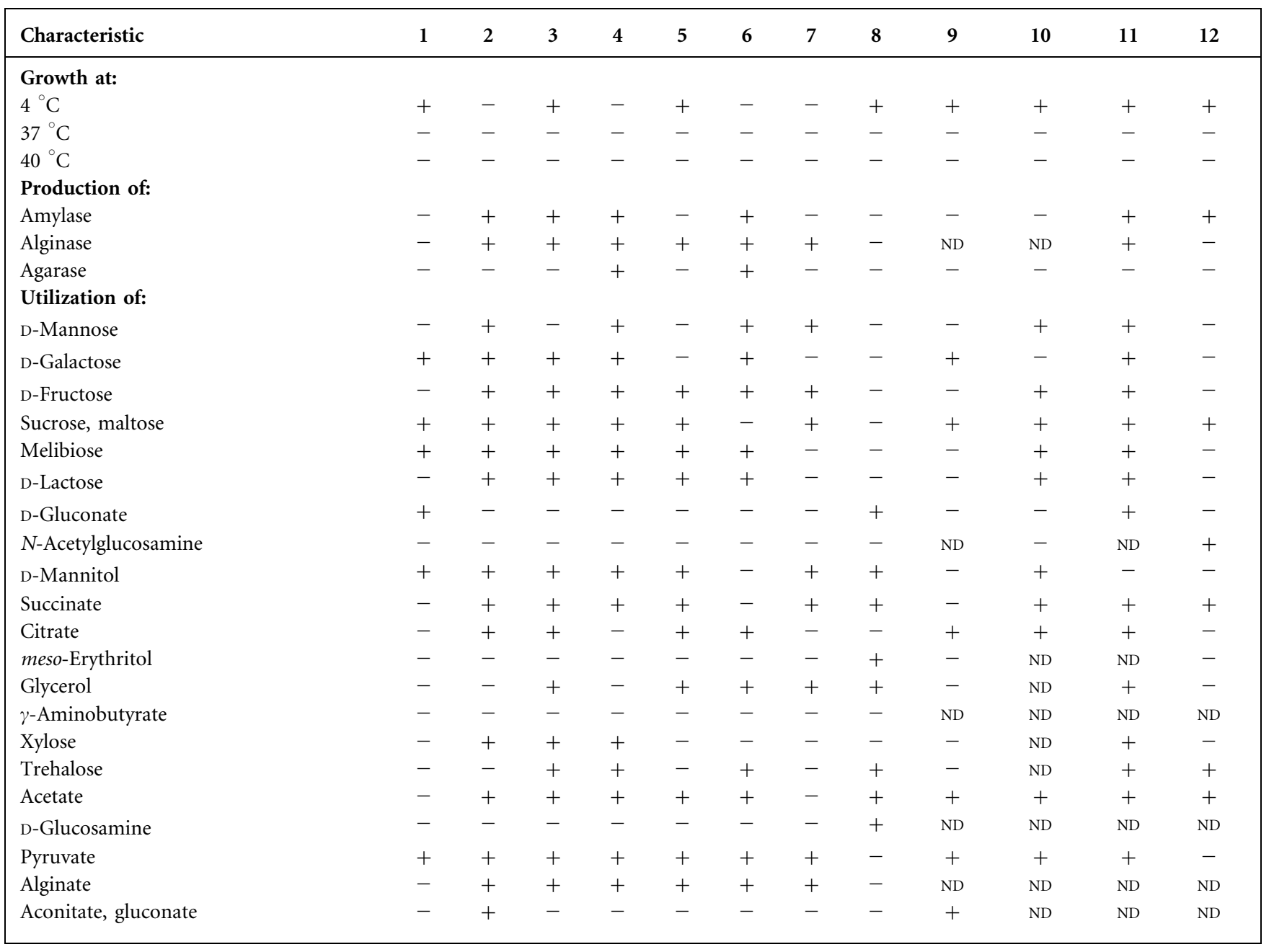

was very high (99\%). This strongly indicates that the newly isolated strain is a novel species within the genus Pseudoalteromonas.

\section{Description of Pseudoalteromonas arctica sp. nov.}

Pseudoalteromonas arctica (arc'ti.ca. L. fem. adj. arctica from the Arctic, referring to the site where the type strain was isolated).

Cells are straight, polar-flagellated, Gram-negative and rod-shaped, $0.15-0.2 \mu \mathrm{m}$ wide and $0.4-0.7 \mu \mathrm{m}$ long. They occur singly and are non-spore-forming and strictly aerobic. Colonies on agar medium are slightly orange, circular, smooth and convex. Temperature range for growth is $4-25{ }^{\circ} \mathrm{C}$, with an optimum between 10 and $15{ }^{\circ} \mathrm{C}$. No growth observed at $30^{\circ} \mathrm{C}$. $\mathrm{pH}$ range for growth is $6-8$, with an optimum at $\mathrm{pH} 7-8$. Growth is observed at $0-9 \% \mathrm{NaCl}(\mathrm{w} / \mathrm{v})$, with an optimum between 2 and $3 \%$ $(w / v)$. Growth is observed with $\alpha$-cyclodextrin, dextrin, cellobiose, D-galactose, $\alpha$-D-glucose, maltose, D-mannitol, melibiose, sucrose, pyruvic acid methyl ester, D-gluconic acid, L-alanine, L-alanylglycine, glycyl-L-glutamic acid, Lserine, aesculin, ferric citrate and capric acid. Positive for activities of the following enzymes: pullulanase, protease, $\beta$ glucanase, esterase, pectinase, $\beta$-glucosidase and $\beta$-galactosidase. FAMEs comprise $20.3 \%$ straight-chain saturated FAMEs, $20.2 \%$ terminally branched saturated FAMEs and $56.1 \%$ monounsaturated FAMEs. Phylogenetic analysis reveals a close relationship to $P$. elyakovii, $P$. distincta and $P$. nigrifaciens with $99 \% 16 \mathrm{~S}$ rRNA gene sequence similarity and 47.6, 44.2 and $22.6 \%$ DNA-DNA relatedness, respectively. Habitat: Arctic seawater.

The type strain is A $37-1-2^{\mathrm{T}} \quad\left(=\mathrm{LMG} 23753^{\mathrm{T}}=\mathrm{DSM}\right.$ $\left.18437^{\mathrm{T}}\right)$, isolated from seawater samples taken from Spitzbergen. The DNA G $+\mathrm{C}$ content of the type strain is $39 \mathrm{~mol} \%$. 
Table 2. Comparative fatty acid content (\%) of the novel strain and related strains belonging to the genus $P$ seudoalteromonas

Strains: 1, A $37-1-2^{\mathrm{T}} ; 2$, P. haloplanktis CECT $4188^{\mathrm{T}} ; 3$, P. tetraodonis IAM $14160^{\mathrm{T}}$ (Ivanova et al., 2001); 4, P. agarivorans $\mathrm{KMM} 255^{\mathrm{T}}$ (Romanenko et al., 2003); 5, P. atlantica IAM 14164 (Bozal et al., 1997). ND, No data available.

\begin{tabular}{|lrcccc|}
\hline Fatty acid & $\mathbf{1}$ & $\mathbf{2}$ & $\mathbf{3}$ & $\mathbf{4}$ & $\mathbf{5}$ \\
\hline $10: 03-\mathrm{OH}$ & 1.2 & $\mathrm{ND}$ & $\mathrm{ND}$ & $\mathrm{ND}$ & 1.4 \\
$12: 0$ & 2.4 & 2.0 & 1.5 & 1.8 & 2.5 \\
$11: 03-\mathrm{OH}$ & 1.1 & 0.3 & 0.4 & $\mathrm{ND}$ & 1.8 \\
$13: 0$ & 0.2 & 0.2 & 0.26 & 0.1 & $\mathrm{ND}$ \\
$12: 03-\mathrm{OH}$ & 6.4 & 1.9 & 0.9 & $\mathrm{ND}$ & 3.8 \\
$14: 0$ & 1.1 & 2.0 & 2.0 & 1.1 & 0.7 \\
$15: 1 \omega 8 c$ & 1.8 & 2.3 & 6.3 & 1.2 & $\mathrm{ND}$ \\
$15: 1 \omega 6 c$ & 0.3 & 0.2 & 0.6 & 0.2 & $\mathrm{ND}$ \\
$15: 0$ & 2.2 & 3.3 & 8 & 2.7 & 2.7 \\
$16: 1 \omega 7 c$ & 40.2 & 40.5 & 35.0 & 42.4 & 22.0 \\
$16: 1 \omega 5 c$ & 0.2 & 0 & 0.2 & 0 & $\mathrm{ND}$ \\
$16: 0$ & 12.7 & 30.1 & 18.2 & 27.3 & 19.4 \\
$17: 1 \omega 8 c$ & 5.5 & 6.0 & 10.7 & 5.9 & 8.2 \\
$17: 0$ & 1.5 & 3.9 & 5.5 & 3.4 & 9.6 \\
$18: 1 \omega 9 c$ & 0.3 & 0.2 & 0.2 & 0.2 & $\mathrm{ND}$ \\
$18: 1 \omega 7 c$ & 7.8 & 2.4 & 2.5 & 7.1 & $\mathrm{ND}$ \\
$18: 0$ & 0.4 & 1.9 & 0.6 & 0.6 & 1.9 \\
& & & & & \\
\hline
\end{tabular}

\section{Acknowledgements}

We are thankful to Hauke Trinks for fruitful collaboration and the German Environmental Foundation (DBU) for support.

\section{References}

Baumann, L., Baumann, P., Mandel, M. \& Allen, R. D. (1972). Taxonomy of aerobic marine eubacteria. J Bacteriol 110, 402-429.

Bozal, N., Tudela, E., Rosselló-Mora, R., Lalucat, J. \& Guinea, J. (1997). Pseudoalteromonas antarctica sp. nov., isolated from an Antarctic coastal environment. Int J Syst Bacteriol 47, 345-351.

Buchholz-Cleven, B. E. E., Rattunde, B. \& Staub, K. L. (1997). Screening for genetic diversity of isolates of anaerobic $\mathrm{Fe}(\mathrm{II})$ oxidizing bacteria using DGGE and whole-cell hybridization. Syst Appl Microbiol 20, 301-309.

Cashion, P., Holder-Franklin, M. A., McCully, J. \& Franklin, M. (1977). A rapid method for the base ratio determination of bacterial DNA. Anal Biochem 81, 461-466.

De Ley, J., Cattoir, H. \& Reynaerts, A. (1970). The quantitative measurement of DNA hybridization from renaturation rates. Eur $J$ Biochem 12, 133-142.

Deming, J. W. (2002). Psychrophiles and polar regions. Curr Opin Microbiol 5, 301-309.

Feller, G. \& Gerday, C. (2003). Psychrophilic enzymes: hot topics in cold adaptation. Nat Rev Microbiol 1, 200-208.

Felsenstein, J. (1995). PHYLIP (phylogeny inference package) version 3.65. Distributed by the author. Department of Genome Sciences, University of Washington, Seattle, USA.

Gauthier, G., Gauthier, M. \& Christen, R. (1995). Phylogenetic analysis of the genera Alteromonas, Shewanella, and Moritella using genes coding for small-subunit rRNA sequences and division of the genus Alteromonas into two genera, Alteromonas (emended) and Pseudoalteromonas gen. nov., and proposal of twelve new species combinations. Int J Syst Bacteriol 45, 755-761.

Gerhardt, P., Murray, R. G. E., Wood, W. A. \& Krieg, N. R. (editors) (1994). Methods for General and Molecular Bacteriology. Washington, DC: American Society for Microbiology.

Huß, V. A. R., Festl, H. \& Schleifer, K. H. (1983). Studies on the spectrophotometric determination of DNA hybridization from renaturation rates. Syst Appl Microbiol 4, 184-192.

Ivanova, E. P., Chun, J., Romanenko, L. A., Matte, M. E., Mikhailov, V. V., Frolova, G. M., Huq, A. \& Colwell, R. R. (2000). Reclassification of Alteromonas distincta Romanenko et al. 1995 as Pseudoalteromonas distincta comb. nov. Int J Syst Evol Microbiol 50, 141-144.

Ivanova, E. P., Romanenko, L. A., Matté, M. H., Matté, G. R., Lysenko, A. M., Simidu, U., Kita-Tsukamoto, K., Sawabe, T., Vysotskii, M. V. \& other authors (2001). Retrieval of the species Alteromonas tetraodonis Simidu et al. 1990 as Pseudoalteromonas tetraodonis comb. nov. and emendation of description. Int J Syst Evol Microbiol 51, 1071-1078.

Ivanova, E. P., Sawabe, T., Alexeeva, Y. V., Lysenko, A. M., Gorshkova, N. M., Hayashi, K., Zukova, N. V., Christen, R. \& Mikhailov, V. V. (2002). Pseudoalteromonas issachenkonii sp. nov., a bacterium that degrades the thallus of the brown alga Fucus evanescens. Int J Syst Evol Microbiol 52, 229-234.

Ivanova, E. P., Bakunina, I. Y., Nedashkovskaya, O. I., Gorshkova, N. M., Alexeeva, Y. V., Zelepuga, E. A., Zvaygintseva, T. N., Nicolau, D. V. \& Mikhailov, V. V. (2003). Ecophysiological variabilities in ectohydrolytic enzyme activities of some Pseudoalteromonas species, P. citrea, P. issachenkonii, and P. nigrifaciens. Curr Microbiol 46, 6-10.

Ivanova, E. P., Gorshkova, N. M., Zhukova, N. V., Lysenko, A. M., Zelepuga, E. A., Prokof'eva, N. G., Mikhailov, V. V., Nicolau, D. V. \& Christen, R. (2004). Characterization of Pseudoalteromonas distinctalike sea-water isolates and description of Pseudoalteromonas aliena sp. nov. Int J Syst Evol Microbiol 54, 1431-1437.

Jahnke, K. D. (1992). BASIC computer program for evaluation of spectroscopic DNA renaturation data from GILFORD SYSTEM 2600 spectrophotometer on a PC/XT/AT type personal computer. $J$ Microbiol Methods 15, 61-73.

Kämpfer, P. \& Kroppenstedt, R. M. (1996). Numerical analysis of fatty acid patterns of coryneform bacteria and related taxa. Can J Microbiol 42, 989-1005.

Kimura, M. (1980). A simple method for estimating evolutionary rates of base substitutions through comparative studies of nucleotide sequences. J Mol Evol 16, 111-120.

Kuykendall, L. D., Roy, M. A., O’Neill, J. J. \& Devine, T. E. (1988). Fatty acids, antibiotic resistance, and deoxyribonucleic acid homology groups of Bradyrhizobium japonicum. Int J Syst Bacteriol 38, 358-361.

Mesbah, M. \& Whitman, W. B. (1989). Measurement of deoxyguanosine/thymidine ratios in complex mixtures by high-performance liquid chromatography for determination of the mole percentage guanine + cytosine of DNA. J Chromatogr 479, 297-306.

Miller, L. T. (1982). Single derivatization method for routine analysis of bacterial whole-cell fatty acid methyl esters, including hydroxy acids. J Clin Microbiol 16, 584-586.

Rainey, F. A. \& Stackebrandt, E. (1993). 16S rDNA analysis reveals phylogenetic diversity among the polysaccharolytic clostridia. FEMS Microbiol Lett 113, 125-128.

Romanenko, L. A., Zhukova, N. V., Rohde, M., Lysenko, A. M., Mikhailov, V. V. \& Stackebrandt, E. (2003). Pseudoalteromonas agarivorans sp. nov., a novel marine agarolytic bacterium. Int J Syst Evol Microbiol 53, 125-131. 
Sawabe, T., Tanaka, R., Iqbal, M. M., Tajima, K., Ezura, Y., Ivanova, E. P. \& Christen, R. (2000). Assignment of Alteromonas elyakovii KMM $162^{\mathrm{T}}$ and five strains isolated from spot-wounded fronds of
Laminaria japonica to Pseudoalteromonas elyakovii comb. nov. and the extended description of the species. Int J Syst Evol Microbiol 50, 265-271. 